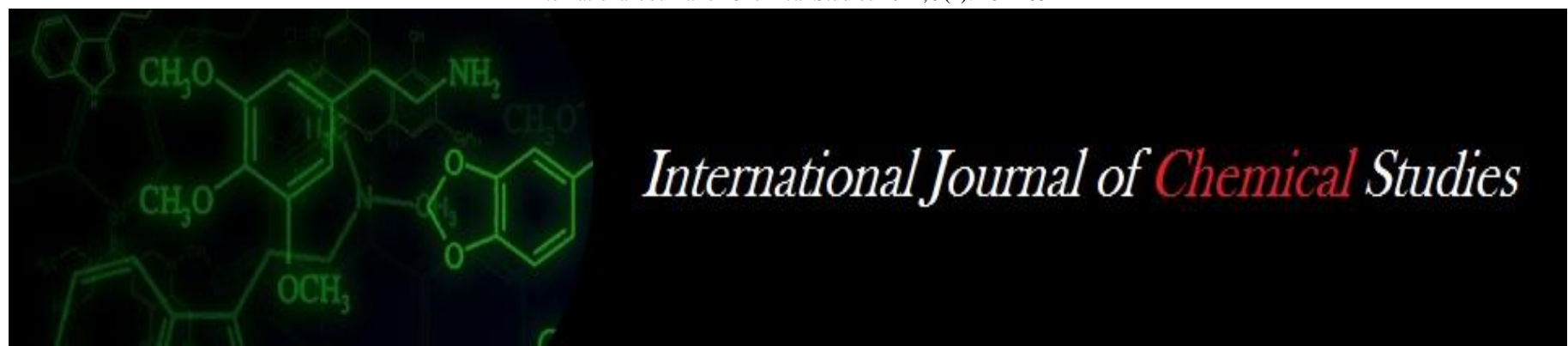

P-ISSN: 2349-8528

E-ISSN: 2321-4902

www.chemijournal.com

IJCS 2021; 9(1): 284-285

(C) 2021 IJCS

Received: 25-10-2020

Accepted: 02-12-2020

Feroz Ahmad Parry

Assistant Professor, Mountain

Agriculture Research \&

Extension Station Gurez,

SKUAST-K, Jammu and

Kashmir, India

Waseem Ali Dar

Assistant Professor, Mountain

Agriculture Research \&

Extension Station Gurez,

SKUAST-K, Jammu and

Kashmir, India

Bilal Ahmad Bhat

Assistant Professor, Mountain

Agriculture Research \&

Extension Station Gurez,

SKUAST-K, Jammu and

Kashmir, India
Corresponding Author: Feroz Ahmad Parry Assistant Professor, Mountain Agriculture Research \& Extension Station Gurez, SKUAST-K, Jammu and Kashmir, India

\section{Effect of organic manures and bio-fertilizers on growth and yield of French bean under high altitude rain fed climatic conditions of Gurez- Jammu and Kashmir}

\author{
Feroz Ahmad Parry, Waseem Ali Dar and Bilal Ahmad Bhat
}

DOI: https://doi.org/10.22271/chemi.2021.v9.i1d.11241

\section{Abstract}

A field experiment was conducted at experimental farm of Mountain Agriculture Research and Extension Station Gurez, SKUAST-K (J\&K) with five treatments comprising (control, Sheep manure@20 t ha${ }^{1}$,FYM @ $24 \mathrm{t} \mathrm{ha}{ }^{-1}$,Vermi-Compost @ $8 \mathrm{t} \mathrm{ha}^{-1}$ and sheep manure 5t+FYM 6t+vermi-compost $2 t+$ Rhizobium $2.5 \mathrm{kgha}^{-1}$ during kharif -2019 to find out the response of different sources of organic manures and bio-fertilizers on growth and yield parameters of french bean under high altitude rain fed climatic conditions. Among the treatments studied, significantly highest plant height $(57.33 \mathrm{~cm})$, No. of pods plant ${ }^{-1}(38.33)$, pod yield plant ${ }^{-1}(240.00 \mathrm{~g})$, pod yield plot $^{-1} 14.40 \mathrm{~kg}$ and pod yield $319.99 \mathrm{q}$ hectare $^{-1}$ were noticed with the integrated application of organic manures and bio-fertilizer (sheep manure $5 \mathrm{t}+$ FYM $6 \mathrm{t}+$ vermi-compost $2 \mathrm{t}+$ Rhizobium $2.5 \mathrm{~kg} \mathrm{ha}^{-1}$ ).

Keywords: Bio-fertilizer, french bean, high altitude, organic manure, rainfed

\section{Introduction}

French bean (Phaseolus vulgaris L.) is one of the popular and nutritious crops among leguminous vegetables across the world. It is also known as common bean or kidney bean. It is consumed as green pods and shell beans and is quite rich source of protein, vitamins, calcium and iron (Sharma et al., 2016) ${ }^{[6]}$. French bean is grown extensively because of its short duration and for nutritive values. One of the factors of low productive french bean is due to inadequate fertilization. Recently, the use of organic materials as fertilizers for crop production has received attention for sustainable crop productivity (Tejada et al., 2009) ${ }^{[10]}$. Organic materials hold great promise as a source of multiple nutrients and ability to improve soil characteristics (Moller, 2009) ${ }^{[4]}$. Organic manures act not only as a source of nutrients and organic matter, but also increases pod size, biodiversity and activity of the microbial population in soil, influence structure, nutrient turnover and many other related physical, chemical, and biological parameters of the soil (Manivannan et al., 2009) ${ }^{[3]}$. Organic manures helps to increase the population of soil micro-organisms which influence in protecting plant against pathogen like nematodes and soil borne insects and also provide growth hormones like auxin (Agbedge and Ojeniyi, 2009) ${ }^{[1]}$. The synthetic fertilizers are harmful to soil and aerial environment a threat to entire globe, because the inorganic fertilizers mainly contain major nutrients NPK in large quantities and are neglecting the use of organic manures and biofertilizes and hence have the way for deterioration of soil health and in turn ill-effects on plants, human being and livestock (Choudhary, 2005) ${ }^{[9]}$. French bean being a short duration leguminous crop, organic cultivation of this crop is preferable, which increases its quality with minimum residual effects. Keeping the importance of french bean as a cash crop of tribal people in Gurez Valley, an investigation has been carried out to find the effect of organic manures and bio-fertilizers on growth and yield of french bean under high altitude rain -fed climatic conditions.

\section{Material and Methods}

The experiment was conducted at Experimental Farm of Mountain Agriculture Research and Extension Station, Gurez, SKUAST-K during kharief-2019 as an off-season vegetable and the 
experiment was layed out in randomized complete block design (RCBD) with five treatments viz, $\mathrm{T}_{1}=$ control, $\mathrm{T}_{2}=$ sheep manure@20 tha ${ }^{-1}, \mathrm{~T}_{3}=$ farm yard manure $(\mathrm{FYM}) @ 24 \mathrm{t}$ $\mathrm{ha}^{-1}, \mathrm{~T}_{4=}$ vermi-compost @ $8 \mathrm{t} \mathrm{ha}^{-1}$ and $\mathrm{T}_{5}=$ sheep manure $5 \mathrm{t}+\mathrm{FYM} \quad 6 \mathrm{t}+$ vermi-compost $2 \mathrm{t}+$ Rhizobium $2.5 \mathrm{kgha}^{-1}$, replicated three times. Gurez is a tribal area located at an altitude of ( $8000 \mathrm{ft}$ above msl) in the northern areas of Jammu and Kashmir Union Territory. The soil has $\mathrm{pH} 7.0$, E.C0.85dsm1, OC 0.51\%, avg. N $340 \mathrm{~kg} / \mathrm{ha}$, avg. P35 kg/ha, avg. K $230 \mathrm{~kg} / \mathrm{ha}$. The field was cleared manually, ploughed and weeded before seedbeds were marked and demarked. The seeds of french bean var. Anupama were sown in plots of 3.0 $\times 1.5 \mathrm{~m}$ size in the $1^{\text {st }}$ week of June. The row to row spacing of $50 \mathrm{~cm}$ and plant to plant spacing of $15 \mathrm{~cm}$ has been adapted. 15 days after germination, the thinning activities have been done. The sources of different organic manures tried in experiment were applied at the time of land preparation. The seeds of particular treatment were mixed with Rhizobium culture @ $2.5 \mathrm{~kg} \mathrm{ha}^{-1}$ and dried under shade before sowing. Agronomic cultural practices recommended by SKUAST-K were adopted to raise the crop. Observations on various growth and yield related attributes were recorded, using standard procedures. The data thus collected was subjected to analysis of variance, using the method proposed by Panse and Sukhatme (1978) ${ }^{[5]}$.

\section{Results and Discussion Growth and Yield Parameters}

It is evident from the date presented in Table 1, that there was significant difference among treatments tried in experiment related to growth and yield related attributes of french bean. Among different treatments, $\mathrm{T}_{5}$-sheepmanure $5 \mathrm{t}+\mathrm{FYM}$ $6 \mathrm{t}+$ Vermi-compost $2 \mathrm{t}+$ Rhizobium $2.5 \mathrm{kgha}^{-1}$ registered highest plant height $(57.33 \mathrm{~cm})$, number of pods per plant (38.33), pod yield per plant $(240 \mathrm{~g})$, pod yield per plot (14.40 $\mathrm{kg}$ ) and yield per hectare (319.99 q) followed by $\mathrm{T}_{4^{-}}$Vermicompost @ $8 \mathrm{t}$ and $\mathrm{T}_{5}$ was found statistically significant as compared to rest of the treatments.

The improvement of growth and yield parameters of french bean might be due to the combined application of different organic manures and bio-fertilizer that influenced the physical and chemical properties of soil (pH 7.5, E.C $1.2 \mathrm{dsm} 1$, OC $0.75 \%$, avg. N $420 \mathrm{~kg} / \mathrm{ha}$, avg. P50 kg/ha, avg. K 280kg/ha) and easy availability of macro and micro nutrients, increase in enzymatic activities leading to better growth and development. Similar results were reported by Singh et al., 2009; and Sharma (2011) [9, 7]. Application of organic manures improve the soil structure, aeration, buffer capacity, water holding capacity, influences the solubility of minerals and provide energy for growth and development of microorganisms (Sharma et al., 2014) ${ }^{[8]}$.

Table 1: Effect of organic manures and bio-fertilizers on growth and yield of French bean

\begin{tabular}{|c|c|c|c|c|c|}
\hline Treatments & Plant ht (cm) & No. of pods/pl & Pod Yield/pl (g) & Pod yield/plot (kg) & Pod yield/ha (q) \\
\hline $\mathrm{T}_{1}-$ Control & 38.66 & 17.33 & 133.33 & 8.00 & 177.77 \\
\hline $\mathrm{T}_{2}-\mathrm{S} . \mathrm{M} @ 20 \mathrm{th}^{-1}$ & 44.66 & 24.00 & 156.66 & 9.40 & 208.88 \\
\hline $\mathrm{T}_{3}-\mathrm{FYM} @ 24 \mathrm{t} \mathrm{ha}^{-1}$ & 49.66 & 27.66 & 180.00 & 10.80 & 239.99 \\
\hline $\mathrm{T}_{4}-\mathrm{V} . \mathrm{C} @ \mathrm{O} 8 \mathrm{tha}^{-1}$ & 52.66 & 33.66 & 210.00 & 12.60 & 279.99 \\
\hline $\mathrm{T}_{5}-\mathrm{S} . \mathrm{M} 5 \mathrm{t}+\mathrm{FYM} 6 \mathrm{t}+\mathrm{V} . \mathrm{C} 2 \mathrm{t}+$ Rhizobium $2.5 \mathrm{kgha}^{-1}$ & 57.33 & 38.33 & 240.00 & 14.40 & 319.99 \\
\hline C.D $(\mathrm{P} \leq 0.05)$ & 2.39 & 2.69 & 17.80 & 1.06 & 23.73 \\
\hline C.V & 2.57 & 4.99 & 5.06 & 5.06 & 5.06 \\
\hline
\end{tabular}

\section{Conclusion}

Application of different organic manures and bio-fertilizer had a significant response on growth and yield of French bean under high altitude rain fed climatic conditions. The results obtained revealed that French bean responded well to the integrated application of different organic manures and biofertilizer to other treatments in the study. Based on the findings of this study, it may be recommended that Sheep manure 5t+FYM6t+Vermi-compost 2t+Rhizobium2.5 kg ha-1 is adequate for maximum growth and yield of French bean in the study location.

\section{References}

1. Agbede TM, Ojeniyi SO. Tillage and poultry manure effects on soil fertility and sorghum yield in southwestern Nigeria. Soil and Tillage Research 2009;64:209.

2. Choudhry AU. Higher value organics, 2005,35-8p. Pakistan and Gulf Economist potter, N.N and J.H. Hotchikiss. Food Science and CBS publishers, New Delhi, India 1997,403p.

3. Manivannan S, Balamurugan M, Parthasarathi $\mathrm{K}$, Gunasekaran G, Rangananathan LS. Effect of soil fertility and crop productivity-beans (Phaseolus vulgaris L.) J. Environ Biol 2009;30(2):275-281.

4. Moller K. Influence of different manuring systems with and without biogas digestion on soil organic matter and nitrogen inputs, flows and budgets in organic cropping systems. Nutr. Cycling Agroecosyst 2009;84:179-202
5. Panse VG, Sukhatme PV. Statistical methods for Agricultural Workers. ICAR, New Delhi 1978.

6. Sharma A, Sharma RP, Singh S. Influence of rhizobium inoculation, split nitrogen application and plant geometry on productivity of garden pea (Pisum sativum L.) in an acid alfisol. Legume Res 2016;39(6):955-961.

7. Sharma I, Phookan DB, Boruah S. Effect of organic manures and bio-fertilizers on yield and economics of cabbage (Brassica oleracea var.capitata). J. Eco-friendly Agric 2011;6(1):6-9.

8. Sharma A, Sharma RP, Sharma GD, Sankhyan NK, Sharma M. Integrated Nutrient Supply for cauliflowerFrench bean-okra cropping sequence in humid temperate zone of north-western Himalayas. Indian J. Hort 2014;71:211-216.

9. Singh SP, Choudhary R, Mishra AK. Effect of different combinations of organic manure on growth and yield of ginger (Zinziber officinale.Rose.). J. Eco-friendly Agric 2009;4(1):22-24.

10. Tejada M, Hermandez MT, Garcia C. Soil restoration using composted plant residues: Effects on soil properties. Soil and Tillage Res 2009;102:109-117. 